Indexed by

\title{
COMPRESSIVE STRENGTH AND DURABILITY PERFORMANCE OF MORTAR CONTAINING PALM OIL BOILER CLINKER AGGREGATE, RICE HUSK ASH, AND CALCIUM BENTONITE
}

Kamolchanok Kueaket

Prince of Songkla University, Faculty of Engineering, Department of Mining and Materials Engineering, Hat Yai, Thailand

\author{
Danupon Tonnayopas \\ Prince of Songkla University, \\ Faculty of Engineering, \\ Department of Mining and \\ Materials Engineering, \\ Hat Yai, Thailand
}

Key words: palm oil boiler clinker, rice husk ash, calcium bentonite, compressive strength, durability against sulphuric acid and sodium sulphate attacks

\section{Cite article:}

Kamolchanok, K., \& Danupon, T. [2021]. Compressive strength and durability performance of mortar containing palm oil boiler clinker aggregate, rice husk ash, and calcium bentonite. Journal of Applied Engineering Science, 19(1), 193 - 203. DOl:10.5937/jaes0-27580

Online aceess of full paper is available at: www.engineeringscience.rs/browse-issues 


\title{
COMPRESSIVE STRENGTH AND DURABILITY PERFORMANCE OF MORTAR CONTAINING PALM OIL BOILER CLINKER AGGREGATE, RICE HUSK ASH, AND CALCIUM BENTONITE
}

\author{
Kamolchanok Kueaket, Danupon Tonnayopas* \\ Prince of Songkla University, Faculty of Engineering, Department of Mining and Materials Engineering, \\ Hat Yai, Thailand
}

The utilization of local waste by-products as a building material has attracted great attention for an environmental sustainability and become a fundamental part of sustainable construction. In this experimental research, the local palm oil industrial waste and agricultural waste are utilized for the green mortar production. To examine the compressive strength and the durability performance of the green mortar mixtures, Palm oil boiler clinker (POBC) was used as a substitution material for natural fine aggregate. An ordinary Portland cement was partially replaced by rice husk ash (RHA) and calcium bentonite (CB) in the proportion of $10 \%, 20 \%$, and $30 \%$ by weight of cement. The compressive strength, water absorption, porosity, durability against sulphuric acid and sodium sulphate attacks, and microstructures of the POBC mortar mixtures were evaluated at the curing age of 7,28 , and 56 days. The experimental results revealed that the compressive strength, water absorption, porosity, and durability characteristics of POBC mortar incorporating RHA and CB were improved by long-term curing. Particularly, the 56-day POBC mortar incorporating up to $30 \%$ of RHA and $10 \%$ of CB yielded the superior durability against sulphuric acid and sodium sulphate attacks.

Key words: palm oil boiler clinker, rice husk ash, calcium bentonite, compressive strength, durability against sulphuric acid and sodium sulphate attacks

\section{INTRODUCTION}

The exploitation of waste materials in mortar and concrete is studied as a means toward a sustainable, environmental-friendly construction [1]. Currently, the practice of using the industrial by-products as supplementary cementitious materials (SCMs) and as an aggregate substitution is spreading constantly. Apart from strength properties, durability is an important issue for local mortar production. Several studies reported that the introduction of the SCMs from waste by-products such as fly ash, silica fume, ceramic waste, ground granulated blast-furnace slag, and rice husk ash can improve the long-term durability of the cementitious composite. This is due to the formation of calcium silicate hydrate by the pozzolanic reaction which improves the pore structure and clogs up the cement matrix [2-6].

The palm oil boiler clinker (POBC) is a waste-by product of palm oil mill [7]. In 2019, the agricultural productivity of palm oil in Thailand was 16.8 million tons [8]. Particularly, the vast cultivation area of palm trees covers 6,765 $\mathrm{km}^{2}$, with an approximate annual crude palm oil production of 2.4 million tons [9]. A solid wastes of crude palm oil production (such as palm fibers, empty fruit bunch, palm shells) are used as biomass fuels in boiler for sterilization process [10]. The POBC and palm oil fuel ash (POFA) are derived after the end of combustion in boiler. The POBC, POFA, and several industrial wastes derived from the palm oil industry have resulted in a significant environmental impact and landfill usage [11-12]. In an ef- fort to mitigate this, the POBC properties were tackled by various researchers. The study on the feasibility of using the waste of palm oil mill for construction applications confirmed that the utilization of palm oil clinker as a sand replacement can reduce the cost of construction and carbon emission by $17 \%$ and $9.6 \%$ compared to that of using natural river sand [13]. In addition, the use of high replacement ratio of palm oil clinker as a sand substitution caused a 56-day mortar's strength reduction of only $22 \%$, as compared to conventional sand mortar [14].

Rice husk ash (RHA); an agricultural by-product, is obtained after using the rice husk as a local biomass fuel. The main constituent of RHA is the reactive amorphous $\mathrm{SiO}_{2}$ [15], therefore, several studies investigated its contribution to the properties of cementitious materials when used as an additive. It was confirmed through an XRD analysis that the addition of reactive $\mathrm{SiO}_{2}$ derived from RHA reacted with the $\mathrm{Ca}(\mathrm{OH})_{2}$ contents of the hydration products [16]. Thus, consuming a portion of the free $\mathrm{Ca}(\mathrm{OH})_{2}$ and forming the additional calcium silicate hydrate $(\mathrm{C}-\mathrm{S}-\mathrm{H})$ gel. Moreover, it was found that the pozzolanic reaction was promoted by the addition of RHA [1718]. The promoted pozzolanic reaction contributed to the strength development and increased C-S-H content. As a reactive filler, $\mathrm{C}-\mathrm{S}-\mathrm{H}$ plays an important role in reducing the capillary pore size in the cement paste. Moreover, utilizing the RHA as supplementary cementitious material can enhance the acid resistance of recycle-aggregate concrete by decreasing calcium hydroxide $\left(\mathrm{Ca}(\mathrm{OH})_{2}\right)$ content, while strengthening the bond between the dif- 
ferent phases within microstructure [19]. This explains the mortar's enhanced durability by the additional $\mathrm{C}-\mathrm{S}-\mathrm{H}$, since the C-S-H forms by cement hydration and pozzolanic reaction. The deterioration reaction between the hydration product of the cement paste and sulphuric acid is the depletion of $\mathrm{Ca}(\mathrm{OH})_{2}$ and the forming of gypsum $\left(\mathrm{CaSO}_{4} \cdot 2 \mathrm{H}_{2} \mathrm{O}\right)$. Then, the degradation mechanisms by sulphuric acid attack occur. Subsequently, the gypsum gel can fill up the pore, intensive gypsum deposit, and the pore structure damaged [20-21].

Furthermore, calcium bentonite $(\mathrm{CB})$ is a natural pozzolanic material and contains more than $60 \%$ of $\mathrm{SiO}_{2}$ [22]. According to the assessment of the strength activity index (SAI) of concrete containing $\mathrm{CB}$, the addition of up to $25 \%$ CB by weight of cement can provide a satisfactory SAI (more than 75\%). Likewise, the compressive strength of concrete containing $15 \%$ CB by weight of cement is close to that of control concrete at the age of 28 days (the strength reduction was only $5 \%$ in comparison with the compressive strength of the control concrete specimen) [23]. In addition, the longer curing periods have a positive impact on improving the strength and durability characteristic of the mortar containing CB [24]. Besides, the addition of $8 \%$ CB decreased the porosity of 28-day mortar by $16.9 \%$ [25-26].

In the pursuit of promoting sustainable construction, this research focuses on the utilization of local by-products as both a fine aggregate substitution and a cement replacement. Therefore, in this study, the RHA and CB were introduced as a partial cement replacement, along with a $100 \%$ POBC fine aggregate replacement to determine the strength and durability characteristics of the mortar mixtures at different curing ages. The strength and durability characteristics; namely, the compressive strength, porosity, water absorption, and resistance to mild concentration of sulphuric acid and sodium sulphate attack were investigated together with the microstructural characterization via scanning electron microscope (SEM).

\section{MATERIALS AND METHODS}

\section{Materials}

An ordinary Portland cement (OPC) complying with ASTM C150 [27], was used in this study, while the RHA derived after raw rice husk (a local by-product from Phattalung province, Thailand) was conventionally burned in open air as a local biomass fuel. Moreover, the calcium bentonite (commercial grade) was purchased from a manufacturer in Saraburi province, Thailand. Meanwhile, the POBC was collected from the waste disposal area near the palm oil plant at Surat Thani province, Thailand.

Firstly, the obtained RHA was then exposed to a temperature of $700^{\circ} \mathrm{C}$ for 1 hour in a muffle furnace in order to eliminate some presence of unburned carbon and/or some organic matter contaminants. Then, it was ground with a jar mill at $70 \mathrm{rpm}$ for 12 hours. The particle size distributions of the RHA and CB were analyzed by a laser particle analyzer (LPSA); model: Analysette 22 Nano tec. The mean particle size $\left(d_{50}\right)$ of RHA and CB was 12.4 and $2.5 \mu \mathrm{m}$, respectively. Regarding the POBC, it was washed to remove any clay particles and organic matter. Then, it was oven-dried at $105 \pm 5^{\circ} \mathrm{C}$ for 24 hours, to be crushed with jaw crusher and sieved through No.4 sieve mesh (or aperture size of $4.75 \mathrm{~mm}$ ). The fresh $\mathrm{POBC}$ samples obtained from palm oil mill disposal area, crushed $\mathrm{POBC}, \mathrm{RHA}$, and $\mathrm{CB}$ powders are depicted in Figure 1. The chemical composition of the POBC, RHA, and $\mathrm{CB}$ were analyzed via a wavelength dispersive X-ray fluorescence spectrophotometer (WDXRF); model: Zetium, and it is expressed in Table 1. The total amount of $\mathrm{SiO}_{2}, \mathrm{Al}_{2} \mathrm{O}_{3}$, and $\mathrm{Fe}_{2} \mathrm{O}_{3}$ contents of $\mathrm{RHA}$ and $\mathrm{CB}$ were higher than $70 \%$, which met the chemical requirements of class $\mathrm{N}$ (raw or calcined natural pozzolans) and class F (fly ash) as per ASTM C618-19 [28]. The percentage passing results of the sieve analysis for crushed $P O B C$, $\mathrm{RHA}$, and $\mathrm{CB}$ were plotted against particle diameters and presented in Figure 2. Finally, the physical proper-

Table 1: Chemical composition of POBC, RHA, and CB analyzed by WDXRF

\begin{tabular}{|c|c|c|c|c|c|c|c|c|c|c|}
\hline Oxides (wt.\%) & $\mathrm{SiO}_{2}$ & $\mathrm{Fe}_{2} \mathrm{O}_{3}$ & $\mathrm{SO}_{3}$ & $\mathrm{~K}_{2} \mathrm{O}$ & $\mathrm{Al}_{2} \mathrm{O}_{3}$ & $\mathrm{CaO}$ & $\mathrm{MgO}$ & $\mathrm{MnO}$ & $\mathrm{P}_{2} \mathrm{O}_{5}$ & LOI \\
\hline $\mathrm{POBC}$ & 65.23 & 1.78 & 0.04 & 9.56 & 1.66 & 10.00 & 5.37 & 0.17 & 5.50 & 0.04 \\
\hline $\mathrm{RHA}$ & 93.83 & 0.36 & 0.21 & 1.77 & 0.66 & 0.76 & 0.36 & 0.11 & 1.04 & 0.67 \\
\hline $\mathrm{CB}$ & 56.62 & 0.02 & 0.69 & 0.96 & 19.81 & 1.16 & 0.55 & 0.03 & 0.05 & 10.12 \\
\hline
\end{tabular}

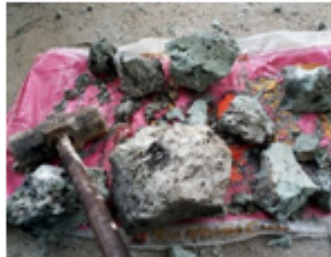

(a)

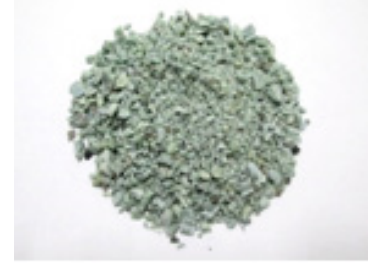

(b)

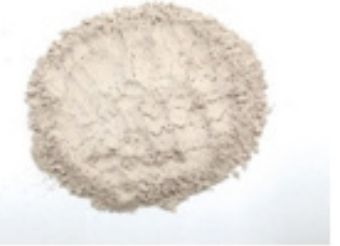

(c)

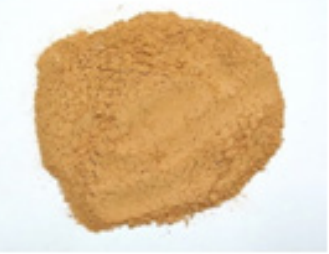

(d)

Figure 1: Lumps of POBC collected from palm oil mill disposal area (a), Crushed POBC (b), RHA powder (c), and CB powder (d) 
ties of POBC fine aggregate were tested and tabulated in Table 2 for convenience.

\section{Mix proportions}

Seven mortar mixtures were prepared with POBC fine aggregate and incorporating RHA and $\mathrm{CB}$ as an ordinary Portland cement (OPC) replacement. The OPC was partially replaced by $\mathrm{RHA}$ and $\mathrm{CB}$ at the replacement ratios of $10 \%, 20 \%$, and $30 \%$ (by percent weight of OPC), respectively. The mixture proportions are 1:2.75 (Binder: POBC aggregate). Water to binder ratio of the mixture was kept constant at 0.48 in accordance with ASTM C109 [29]. The percentage of flow was carried out as following ASTM C 1437-15 [30]. The mixture series are tabulated in Table 3.

\section{Testing methods}

To determine the compressive strength, water absorption, porosity, and durability against acid and sulphate attacks, three cube specimens of $50-\mathrm{mm}$ of each mixture were cast and then cured in saturated lime water at the temperature of $27 \pm 5^{\circ} \mathrm{C}$ for a period of 7,28 , and 56 days before testing. The compressive strength test was performed according to ASTM C109 [29] by using digital concrete compression machine model $\mathrm{KC}-150 \mathrm{~g}$ with capacity $1,500 \mathrm{kN}$. The strength activity index (SAI) was calculated as per ASTM C618-19 [28]. The water absorption and porosity measurements were conducted in accordance with the Archimedes method based on the ASTM standard C373-14a [31].

The sulphuric acid $\left(\mathrm{H}_{2} \mathrm{SO}_{4}\right)$ and sodium sulphate $\left(\mathrm{Na}_{2} \mathrm{SO}_{4}\right)$ resistance tests were carried out after the specimens were cured in saturated lime water for periods of 7,28 , and 56 days. During testing, the 7-day, 28-day, and 56-day specimens of each mixture were weighted by digital precision balance $(0.001 \mathrm{~g})$, and then exposed to $0.005 \mathrm{M}(\mathrm{pH} \approx 2.5)$ sulphuric acid solution $\left(\mathrm{H}_{2} \mathrm{SO}_{4}\right)$ and $0.5 \mathrm{M}(\mathrm{pH} \approx 8)$ sodium sulphate solution $\left(\mathrm{Na}_{2} \mathrm{SO}_{4}\right)$ for a period of 42 days. The

Table 3: Mix proportions of POBC mortar $\left(\mathrm{kg} / \mathrm{m}^{3}\right)$

\begin{tabular}{|c|c|c|c|c|c|c|}
\hline \multirow{2}{*}{ No. } & Nomenclature & \multicolumn{3}{|c|}{$\begin{array}{c}\text { Binder } \\
\left(\mathrm{kg} / \mathrm{m}^{3}\right)\end{array}$} & $\begin{array}{c}\text { Fine } \\
\text { aggregate } \\
\left(\mathrm{kg} / \mathrm{m}^{3}\right)\end{array}$ & $\begin{array}{c}\text { Flow } \\
(\%)\end{array}$ \\
\cline { 3 - 7 } & & OPC & CB & RHA & POBC & \\
\hline 1 & Control & 500 & 0 & 0 & 1,375 & 121 \\
\hline 2 & R10 & 450 & 0 & 50 & 1,375 & 98 \\
\hline 3 & R20 & 400 & 0 & 100 & 1,375 & 83 \\
\hline 4 & R30 & 350 & 0 & 150 & 1,375 & 75 \\
\hline 5 & B10 & 450 & 50 & 0 & 1,375 & 111 \\
\hline 6 & B20 & 400 & 100 & 0 & 1,375 & 106 \\
\hline 7 & B30 & 350 & 150 & 0 & 1,375 & 97 \\
\hline
\end{tabular}

Table 2: Physical properties of crushed POBC (fine aggregate)

\begin{tabular}{|c|c|}
\hline Crushed POBC properties & Value \\
\hline Loose bulk density $\left(\mathrm{kg} / \mathrm{m}^{3}\right)$ & $1,145.71$ \\
Void $(\%)$ & 32.59 \\
\hline Compacted bulk density $\left(\mathrm{kg} / \mathrm{m}^{3}\right)$ & $1,310.71$ \\
Void (\%) & 22.88 \\
\hline Fineness modulus & 3.74 \\
\hline Specific gravity & 2.20 \\
\hline Soundness (\%) & 2.05 \\
\hline Water absorption (\%) & \\
1 day & 3.13 \\
7 days & 3.94 \\
Moisture content (\%) & 0.80 \\
\hline Organic impurity (ASTM C40-20) & None \\
\hline
\end{tabular}

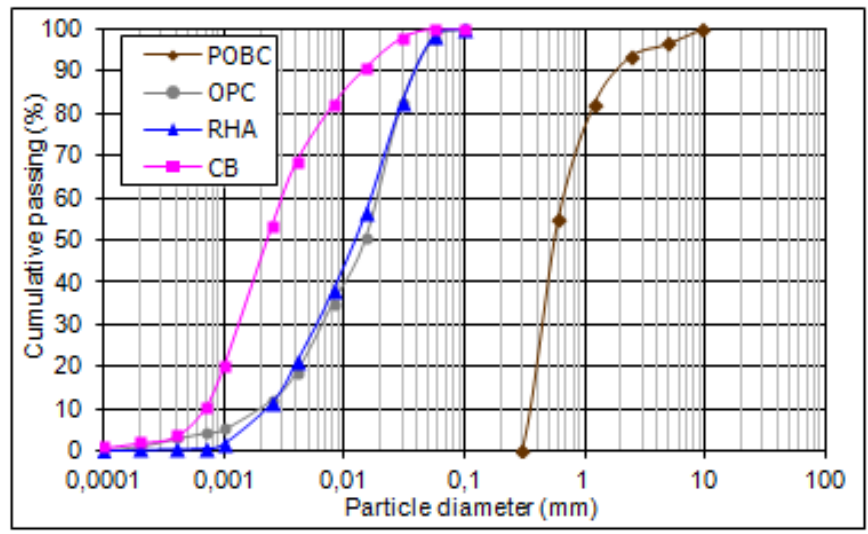

Figure 2: Grading analysis of raw materials

acid and sulphate solutions were refreshed every week, in order to maintain the $\mathrm{pH}$ value and reduce the effect of $\mathrm{pH}$ gaining by excessive lime due to the cement hydration. After 42 days of exposure to each acid and sulphate solutions, the weights and compressive strengths of each specimen were examined. Subsequently, through comparing the weight before and after exposure to the acid and sulphate solutions, the weight loss was estimated. Moreover, the change in compressive strengths after exposure to acid and sulphate solutions was investigated in comparison to the compressive strength of the specimen before exposure, as to assess the compressive strength loss.

For the microstructural analysis of the POBC mortar's cement paste, the scanning electron micrographs were carried out by using Thermo Fisher Scientific scanning electron microscope, model Quanta 400 (SEM-Quanta) at the accelerating voltage of $20 \mathrm{kV}$. 


\section{RESULTS AND DISCUSSIONS}

\section{Compressive strength}

The compressive strength results of the POBC mortars incorporating the RHA and $\mathrm{CB}$ at different ages are presented in Figure 3. Generally, it is evident that the 7-day compressive strengths of the RHA and $\mathrm{CB}$ specimens were lower than the control specimen. However, it can be noticed that the compressive strength of all mix types increased through a prolonged period of curing.

Particularly, it was observed that the mortar incorporating the RHA developed strength gradually in the long term. At the curing age of 56 days, an increase in the compressive strength and strength activity index (SAI) was $16 \%$, $18 \%$, and $15 \%$ for the mortar specimens incorporating $10 \%, 20 \%$, and $30 \% \mathrm{RHA}$, respectively, as compared to that of the control mortar; This is shown in Figure 3(a) and 4 . This increase in the compressive strength of RHA mixtures with age could be due to the high pozzolanic reaction that is gradually promoted by the reactive amorphous $\mathrm{SiO} 2$ contents of the RHA [32-33].

On the other hand, the compressive strength decreased with the increase in the $\mathrm{CB}$ replacement ratio. At the age of 56 days, a decrease in the compressive strength of the CB mixtures was observed to be $9 \%, 15 \%$, and $20 \%$, for the mortars incorporating CB content of $10 \%, 20 \%$, and $30 \%$, respectively; as shown in Figure 3(b). However, the

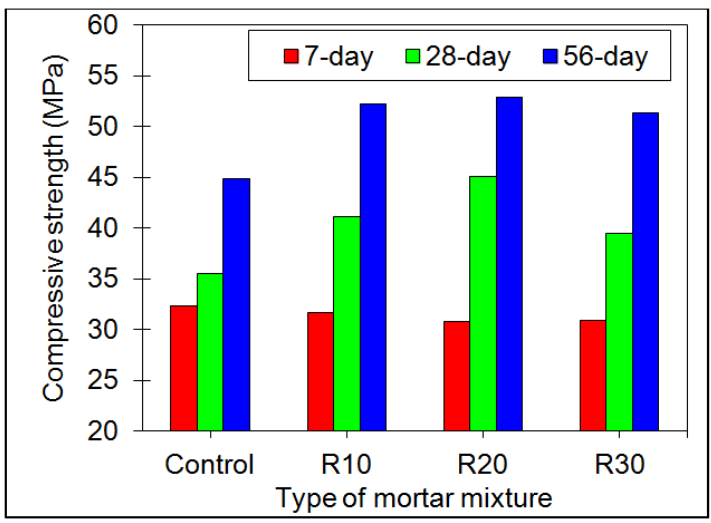

(a)

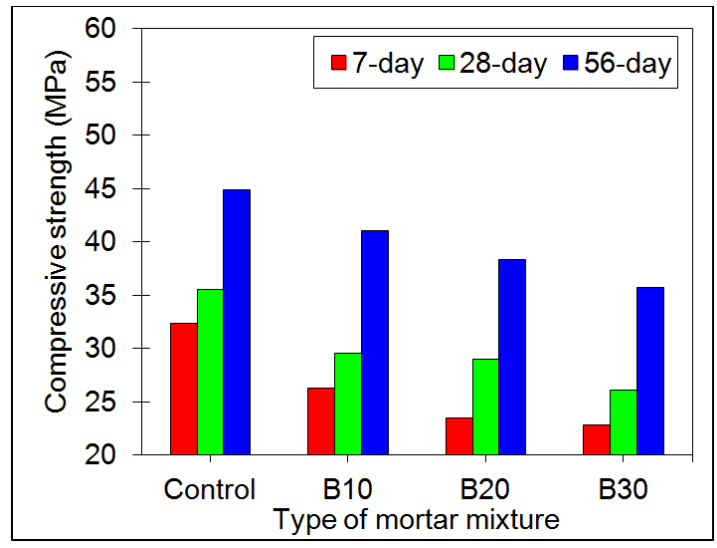

(b)

Figure 3: Compressive strength of $P O B C$ mortar containing RHA (a) and CB (b) at different ages



Figure 4: Strength activity index of $P O B C$ mortar containing RHA and $C B$ at different ages

percentage of the strength development from the age of 28 days to 56 days for the specimens incorporating $0 \%$ and $10 \%$ CB was $26 \%$ and $39 \%$, respectively. Besides, the strength activity indexes (SAI) of the mixture containing $10 \%$ CB content were $81 \%, 83 \%$, and $91 \%$ at the ages of 7,28 , and 56 days, respectively; as shown in Figure 4.

Thus, it is observed that the replacement by weight of OPC by $10 \%$ CB provided the lowest strength reduction and the most desirable SAI, as per the standard requirement of ASTM C618-19 [28]. This finding is in good agreement with the previous studies [24, 34].

\section{Water absorption and porosity}

Figure 5 shows the water absorption and porosity of the POBC mortars incorporating RHA and $\mathrm{CB}$ at the age of 7,28 , and 56 days. In general, the water absorption and porosity of all mixtures decrease as the curing age increases.

An increase in the replacement ratio of the RHA significantly reduced the water absorption and porosity of the RHA specimens, compared to that of the control specimen; as shown in Figure 5(a). At the age of 56 days, both the water absorption and porosity of the specimen incorporating 30\% RHA were lower than the control specimen by $36 \%$ and $33 \%$, respectively. The decrease in porosity could be due to the high pozzolanic reaction and the filler effect of RHA [35].

On the other hand, it was observed that incorporating $10 \%$ CB content reduced the water absorption and porosity by $9 \%$ and $14 \%$, respectively, compared to that of the control specimen at the curing age of 56 days; as shown in Figure 5(b). However, an increase in $C B$ replacement of OPC above $10 \%$ (by weight) showed a negative impact on the water absorption and porosity characteristics of the mortar. This finding is consistent with previous researches [25-26], where it was shown that incorporating $8-15 \%$ CB content can decrease the porosity of mortar. Conversely, they pointed out that the water absorption and porosity of the mortar incorporating 
high replacement ratio of CB (more than $15 \%$ ) increased owing to the high $\mathrm{CB}$ content, which could hinder the hydration reaction. Thus, it could lead to aggravating the more heterogeneous matrix structure of mortar. In addition, an excess CB replacement absorbs additional water content. Consequently, the water absorption of the mortar incorporating a high amount of CB increases [23].

\section{Effects of sulphuric acid attack}

\section{Weight loss}

The weight loss of the specimens containing RHA and $\mathrm{CB}$ at different ages was assessed after 42 days of exposure to $0.005 \mathrm{M}(\mathrm{pH}=2.5)$ sulphuric acid solution, as shown in Figure 6. The overall trend shows a decrease in weight loss with prolonged curing before exposure to sulphuric acid.

The examination of the RHA specimens, clearly demonstrates that an increase in the RHA replacement ratio significantly reduced the weight loss of the RHA specimens compared to that of the control specimen. For instance, the weight loss was $1.53 \%, 0.81 \%, 0.68 \%$ and $0.47 \%$ for the 56-day specimens containing $0 \%, 10 \%, 20 \%$ and $30 \%$ RHA content; as shown in Figure 6(a).

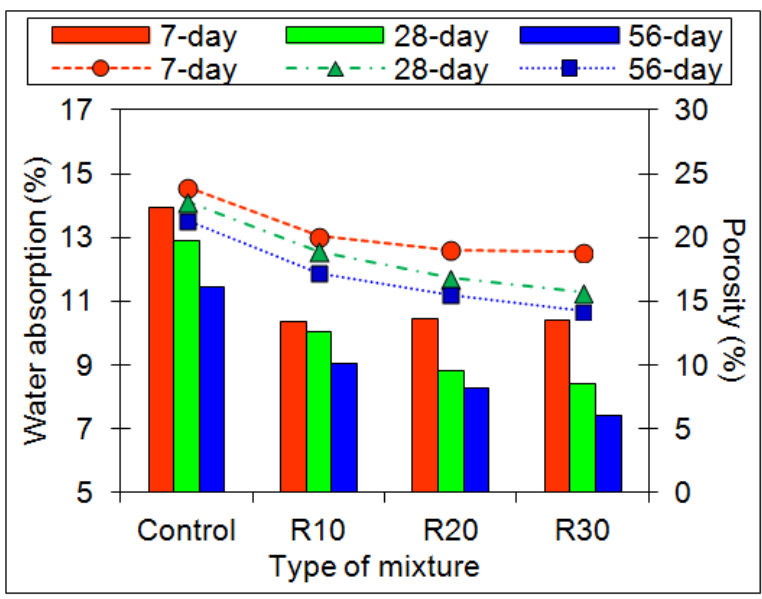

(a)

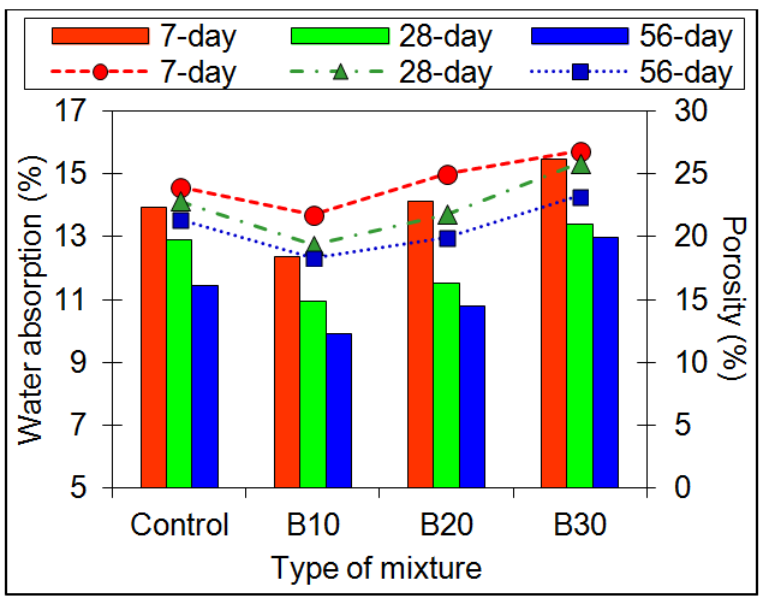

(b)

Figure 5: Water absorption and porosity of $P O B C$ mortar containing RHA (a) and CB (b) at different ages

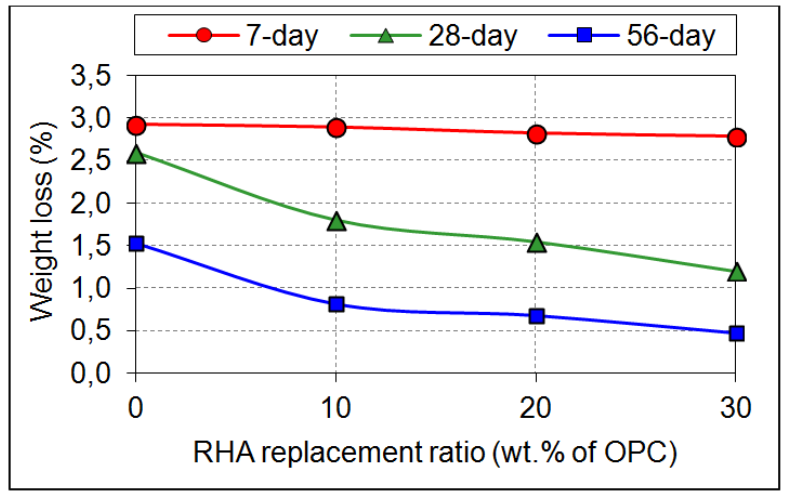

(a)



(b)

Figure 6: Weight loss of POBC mortar containing RHA (a) and $C B$ (b) after exposure to sulphuric acid solution

Likewise, it was found that the 56-day specimen containing $10 \%$ CB content, provided $0.97 \%$ of weight loss, which was lower than that of the control specimen and the specimens containing $20 \%$ and $30 \%$ CB content; as per Figure 6(b). On the contrary, an increase in the $C B$ replacement ratio of more than $10 \%$ performed greater weight loss and has a negative effect on the resistance to sulphuric acid exposure.

\section{Strength loss}

The compressive strength loss values of different mixtures at the curing ages of 7,28 , and 56 days are revealed in Figure 7. Generally, a decrease in the strength loss is noted with an increase in the curing age before the exposure to sulphuric acid. For instance, the strength loss was recorded to be $4.93 \%, 3.84 \%, 2.90 \%$ and $1.59 \%$ for the 56-day specimens incorporating 0\%, 10\%, 20\% and $30 \% \mathrm{RHA}$, respectively, as depicted in Figure $7(\mathrm{a})$. In addition, the 56-day specimen containing CB content of $10 \%$ provided the lower strength loss $(4.43 \%)$, in comparison with the specimen containing $20 \%$ and $30 \%$ CB content; with a strength loss of $5.54 \%$ and $6.08 \%$ (Figure $7(b))$.

Consequently, an increase in RHA replacement ratio of RHA showed a decrease in the strength loss and has a positive effect on sulphuric acid resistance, while the specimen incorporating more than $10 \%$ CB content provided an increase in strength loss and has an adverse 
effect on the resistance of POBC mortar to sulphuric acid attack.

\section{Effects of sodium sulphate attack}

\section{Weight gain}

An increase in weight was observed in all specimens after 42 days of exposure to $0.5 \mathrm{M}(\mathrm{pH}=8)$ sodium sulphate solution, as demonstrated in Figure 8. Generally, there is a mild decrease in the weight gain with exposure to sodium sulphate solution after prolonged curing. For example, the weight gain was $0.13 \%, 0.09 \%, 0.07 \%$ and $0.03 \%$ for the 56 -day specimens incorporating $0 \%, 10 \%$, $20 \%$ and $30 \%$ of RHA, respectively, as presented in Figure $8(a)$. Additionally, it is found that the 56-day specimen incorporating 10\% CB provided the lowest weight gain by $0.12 \%$, whereas the weight gains of the control specimen and the specimens with $20 \%$, and $30 \%$ CB content were $0.13 \%, 0.15 \%$, and $0.16 \%$, respectively, as illustrated in Figure 8(b). Hence, the increase in proportions of RHA replacement of OPC and the specimen incorporating $10 \%$ CB yielded a better performance to sulphate resistance by demonstrating the lower weight gain when compared to that of the control specimen. This result is in agreement with that of [36], who explained that the weight gain after early exposure to sodium sulphate solution (up to 90 days) could be due to the sulphate salt and hydration products were formed.

\section{Strength loss}

Figure 9 presents the compressive strength loss of the RHA and CB mixtures at different curing ages before exposure to the sodium sulphate solution. The overall trend shows a decrease in the strength loss with prolonged curing age for all mixtures.

As for the RHA specimens (Figure 9(a)), it is constantly observed that the strength loss gradually diminishes as the RHA replacement ratio increases. For example, the loss in compressive strength of the 56-day control specimen was $1.15 \%$ while the strength loss of the 56 day specimens incorporating $10 \%, 20 \%$, and $30 \% \mathrm{RHA}$ content was found to be $0.85 \%, 0.55 \%$, and $0.32 \%$, respectively. Furthermore, the strength loss of the 56day specimen containing 10\% CB content was $0.98 \%$ in which was lower than that of the control specimen by $14.78 \%$ (Figure 9(b)). However, an increase in the CB replacement ratio up to $30 \%$ slightly extended the strength loss by $34.69 \%$ compared to that of specimen containing $10 \%$ CB content.

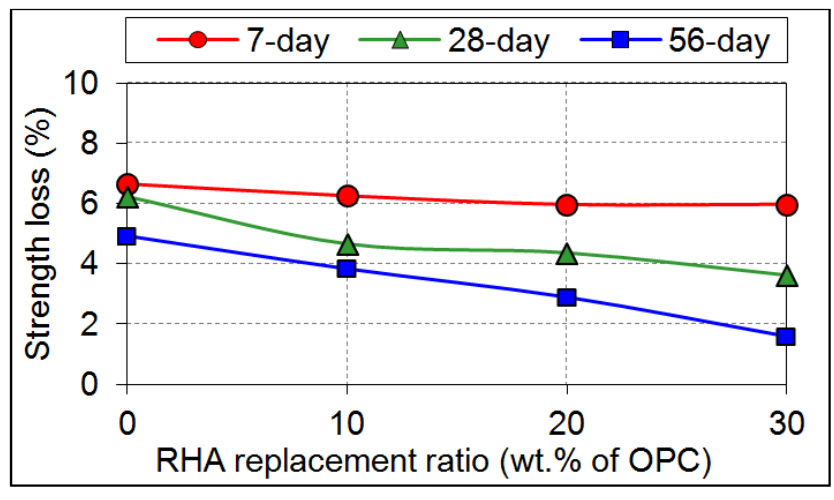

(a)



(b)

Figure 7: Strength loss of $P O B C$ mortar containing RHA (a) and $C B$ (b) after exposure to sulphuric acid solution



(a)

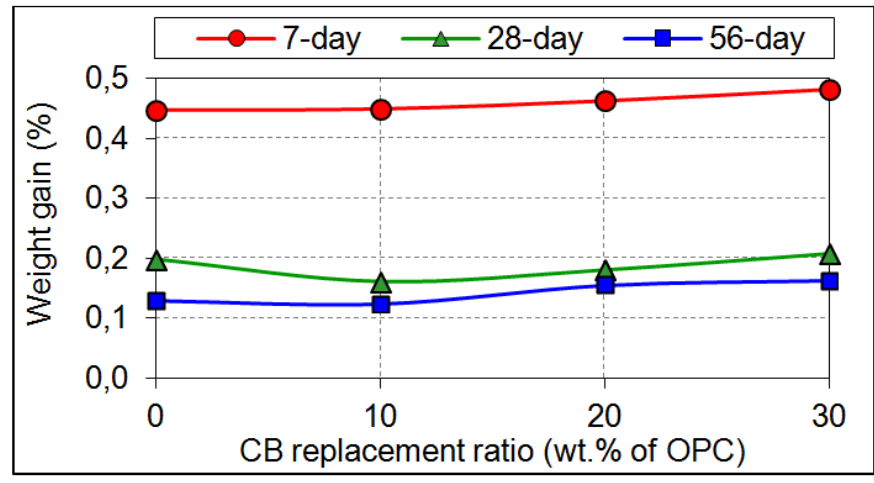

(b)

Figure 8: Weight gain of $P O B C$ mortar containing RHA (a) and $C B$ (b) after exposure to sodium sulphate solution 


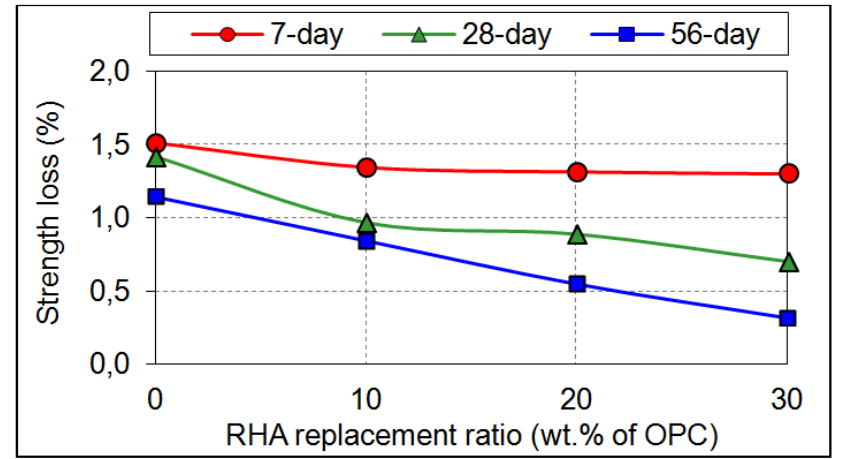

(a)

Figure 9: Strength loss of $P O B C$ mortar containing RHA

\section{Microstructural analysis}

The scanning electron micrographs of the control specimen, specimen incorporating 10\% RHA, and 10\% CB at the ages of 56 days (before exposure to sulphuric acid and sodium sulphate solutions) are demonstrated in Figure 10. It can be observed that the microstructure of each $\mathrm{POBC}$ mortar mixtures consisted of 3 components, including $\mathrm{POBC}$ fine aggregate fragment, cement matrix, and interfacial transition zone (ITZ) located between the $\mathrm{POBC}$ fine aggregate and the cement matrix. As depicted in Figure 10(a)-10(c), the POBC fine aggregate had an angular shape and smooth surface with subconchoid-



(b)

(a) and $C B$ (b) after exposure to sodium sulphate solution

al fracture. In addition, the mixture containing RHA also provided a denser ITZ structure when compared to those of control specimen and CB specimen. The denser ITZ could contributed to the compressive strength improvement of the POBC mortar.

After 42 days of exposure to the sulphuric acid solution $(\mathrm{pH} \approx 2.5)$, alterations of the hydration products were observed under the scanning electron microscope. The photomicrographs of 56-day OPC specimen, specimens incorporating 10\% RHA, and 10\% CB are presented in Figure 11. It can be seen that the acid attack promoted some disintegration features within the microstructures, which accounted for both a weight loss and a strength reduction.

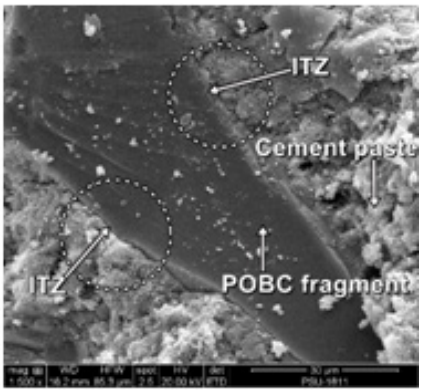

(a)

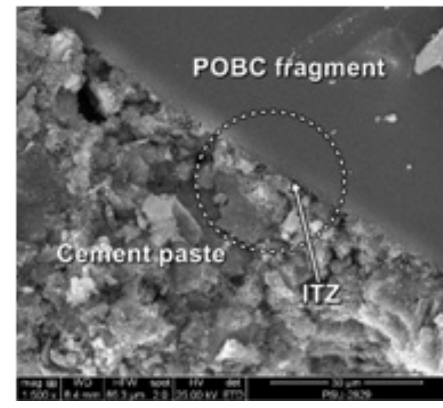

(b)



(c)

Figure 10: Scanning electron micrographs of the 56-day OPC specimen (a), specimen incorporating $10 \%$ RHA (b), and $10 \%$ CB (c) before exposure to sulphuric acid and sodium sulphate solutions



(a)

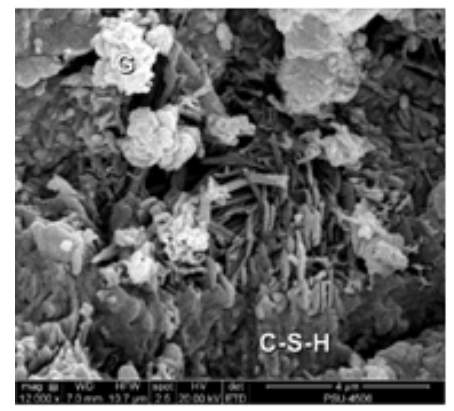

(b)

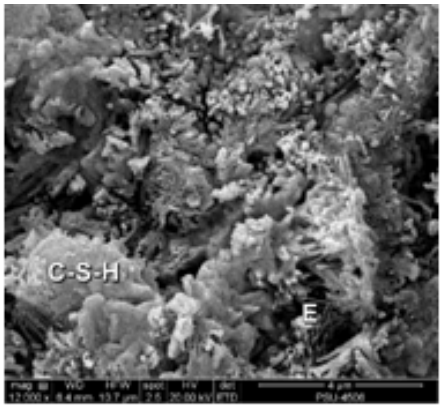

(c)

Figure 11: Scanning electron micrographs of the 56-day OPC specimen (a), specimen incorporating 10\% RHA (b), and $10 \% \mathrm{CB}$ (c) after exposure to sulphuric acid solution for 42 days 
The deleterious mechanism of acid attack is the dissolution of calcium hydroxide (a hydration product of cement paste) and the formation of gypsum $\left(\mathrm{Ca}_{2} \mathrm{SO}_{4} \cdot 2 \mathrm{H}_{2} \mathrm{O}\right)$ and ettringite $\left(\mathrm{Ca}_{6} \mathrm{Al}_{2}\left(\mathrm{SO}_{4}\right)_{3}(\mathrm{OH})_{12} \cdot 26 \mathrm{H}_{2} \mathrm{O}\right)[37-38]$. As a result, the softening of cement paste and the propagating of some microcracks could lead to the weakening of the mortar specimen. The gypsum (a light monoclinic shape with one direction cleavage) and the ettringite (needle-like or elongate prismatic shape) crystals embedded in the matrix of the control specimen, as depicted in Figure 11(a). While a small amount of gypsum and ettringite crystals were observed in the specimens incorporating the RHA and CB supplements, as shown in Figure $11(\mathrm{~b})$ and $11(\mathrm{c})$. In addition, the control specimen revealed less compactness, high porosity, and loosed matrix. Contrastingly, the specimens incorporating either the RHA or CB supplements displayed a denser matrix occupied by the C-S-H framework.

The SEM micrographs of the 56-day OPC specimen, specimen incorporating 10\% RHA, and $10 \%$ CB exposed to sodium sulphate solution $(\mathrm{pH}=8)$ for 42 days, are illustrated in Figure 12. It is apparent that the specimens incorporating the RHA and $\mathrm{CB}$ exhibited lesser pore space and denser matrix (clogged up by $\mathrm{C}-\mathrm{S}-\mathrm{H}$ ), compared to that of the control specimen. Moreover, the less ettringite and microcracks were observed in the specimens incorporating the RHA and CB supplements, as shown in Figure 12(b) and 12(c), when compared to that of the control specimen (Figure 12(a)).

In general, the external sodium sulphate attack mechanism is the penetration of dissoluble sulphate salt into the cement matrix which resulted in weight gain at the early sulphate exposure [39]. Such an attack can provide the deleterious effects on the cement matrix by inducing in the precipitation of sulfoaluminate phase ettringite (E) and gypsum (G) due to the destabilized calcium hydroxide in cement paste reacts with dissoluble sulphate salt. Additionally, the formation of ettringite causes an increase in the volume of the cementitious matrix and induces some micro cracks. Subsequently, the expansion and microcracks could lead to the strength reduction [40-41]. An increase in the densification of the matrix within the POBC mortar incorporating the RHA and $\mathrm{CB}$ supplements could contributed to the pore refinements and reduction of the connectivity of pores, which in turn mitigates the deterioration from the penetration of the dissoluble sulphate salt into the matrix.

\section{CONCLUSIONS}

This study investigated the performance of mortar containing waste materials namely, palm oil boiler clinker as a fine aggregate substitution, the rice husk ash and calcium bentonite as a partial cement replacement. The compressive strength, water absorption, porosity, durability against sulphuric acid and sodium sulphate attacks at the age of 7,28 , and 56 days were examined. Based on the experimental results, the following conclusions are drawn:

- The compressive strengths of the POBC mortar incorporating the rice husk ash (RHA) and calcium bentonite $(\mathrm{CB})$ were enhanced by a prolonged period of curing up to 28 days. The highest SAl of the $\mathrm{RHA}$ and $\mathrm{CB}$ mixtures at the age of 28 and 56 days was obtained in the mixtures containing RHA content of up to $20 \%$ and CB content of $10 \%$.

- The increase in the RHA replacement ratio and the curing ages of POBC mortar have a positive impact on reducing both the water absorption and porosity. Additionally, the POBC mortar incorporating up to $10 \%$ CB provided lower water absorption and porosity compared to the control mixture. However, any increase in the CB replacement ratio of more than $10 \%$ significantly increases the water absorption and porosity.

- The weight variation and strength loss due to sulphuric acid and sodium sulphate attacks of each POBC mortar mixtures were mitigated by increasing the curing duration before such exposure. Evidently, the POBC mortars incorporating the RHA supplement of up to $30 \%$, and $10 \%$ of CB yielded the optimum durability against sulphuric acid and sodium sulphate attack.

- The SEM micrographs revealed that the interfacial transition zones were found to be denser in the mixture incorporating RHA. After exposure to sulphuric acid and the sodium sulphate solutions, the POBC mortars incorporating the RHA and CB provided less

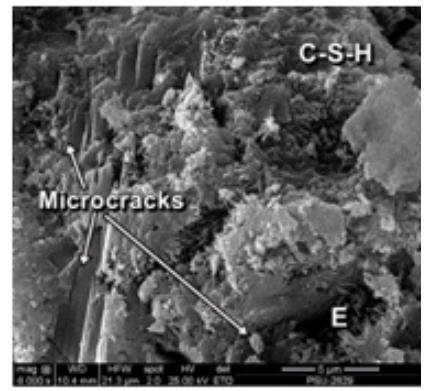

(a)

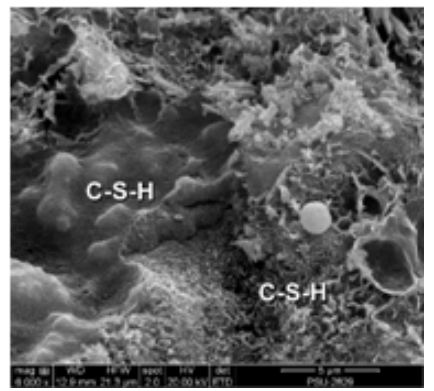

(b)

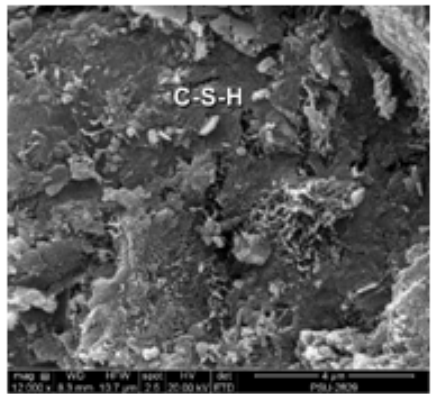

(c)

Figure 12: Scanning electron micrographs of the 56-day OPC specimen (a), specimen incorporating $10 \%$ RHA (b), and $10 \%$ CB (c) after exposure to sodium sulphate solution for 42 days 
disintegration combined with a dense matrix occupied by C-S-H.

The POBC mortar in this study can be served as the non-heavy duty construction materials, eco-brick, and eco-mortar block productions. Besides, the supplement of up to $30 \%$ RHA and $10 \%$ CB can be possibly added as an OPC replacement to alleviate the cement consumption and promote the performance of the POBC mortar against the non-aggressive environment.

\section{ACKNOWLEDGEMENTS}

The authors gratefully acknowledge to the Center of Excellence in Materials Engineering (CEME) and Faculty of Engineering, Prince of Songkla University for the financial support and Graduate Engineering scholarship. Moreover, the first author sincerely expressed the special thanks to the PSU graduate school for PSU.GS. financial support for thesis. Besides, the authors immensely thank to Mr. Sombat Na Bumroong for his help in collecting the POBC samples.

\section{REFERENCES}

1. Martínez-Lage, I., Vázquez-Burgo, P., Velay-Lizancos, M. (2020). Sustainability evaluation of concretes with mixed recycled aggregate based on holistic approach: Technical, economic and environmental analysis. Waste Management, vol. 104, 9-19, DOI: 10.1016/j.wasman.2019.12.044.

2. Liu, K.W., Sun, D.S., Wang, A.G., Zhang, G.Z., Tang, J.H. (2018). Long-term performance of blended cement paste containing fly ash against sodium sulfate attack. Journal of Materials in Civil Engineering, vol. 30, no. 12, 10, DOI: 10.1061/(asce)mt.19435533.0002516.

3. Kumar, V.R.P., Gunasekaran, K., Shyamala, T. (2019). Characterization study on coconut shell concrete with partial replacement of cement by GGBS. Journal of Building Engineering, vol. 26, 9, DOI: 10.1016/j.jobe.2019.100830.

4. Chopra, D., Siddique, R., Kunal. (2015). Strength, permeability and microstructure of self-compacting concrete containing rice husk ash. Biosystems Engineering, vol. 130, 72-80, DOI: 10.1016/j.biosystemseng.2014.12.005.

5. Lim, N., Mohammadhosseini, H., Tahir, M.M., Samadi, M., Sam, A.R.M. (2018). Microstructure and strength properties of mortar containing waste ceramic nanoparticles. Arabian Journal for Science and Engineering, vol. 43, no. 10, 5305-5313, DOI: 10.1007/s13369-018-3154-x.

6. He, Z., Chang, J., Liu, C., Du, S., Huang, M.A.N., Chen, D. (2018). Compressive strengths of concrete containing rice husk ash without processing. Revista Romana de Materiale/ Romanian Journal of Materials, vol. 48 , no. 4, 499-506
7. Kueaket, K., Tonnayopas, D. (2018). Enhanced properties of palm oil boiler clinker concrete with Sang Yod rice husk ash. Journal of Advanced Research in Applied Mechanics, vol. 51, no. 1, 10-19

8. Economics. (2019). Palm oil agricultural statistics of thailand. Ministry of Agriculture and Cooperatives Thailand

9. Nutongkaew, P., Waewsak, J., Riansut, W., Kongruang, C., Gagnon, Y. (2019). The potential of palm oil production as a pathway to energy security in Thailand. Sustainable Energy Technologies and Assessments, vol. 35, 189-203, DOI: 10.1016/j. seta.2019.07.002.

10. Saswattecha, K., Kroeze, C., Jawjit, W., Hein, L. (2016). Options to reduce environmental impacts of palm oil production in Thailand. Journal of Cleaner Production, vol. 137, 370-393, DOI: 10.1016/j.jclepro.2016.07.002.

11. Karim, M.R., Hashim, H., Abdul Razak, H., Yusoff, S. (2017). Characterization of palm oil clinker powder for utilization in cement-based applications. Construction and Building Materials, vol. 135, 21-29, DOI: 10.1016/j.conbuildmat.2016.12.158.

12. Saswattecha, K., Kroeze, C., Jawjit, W., Hein, L. (2015). Assessing the environmental impact of palm oil produced in Thailand. Journal of Cleaner Production, vol. 100, 150-169, DOI: 10.1016/j.jclepro.2015.03.037.

13. Kanadasan, J., Fauzi, A.F.A., Razak, H.A., Selliah, P., Subramaniam, V., Yusoff, S. (2015). Feasibility studies of palm oil mill waste aggregates for the construction industry. Materials, vol. 8, no. 9, 65086530, DOI: 10.3390/ma8095319.

14. Kanadasan, J., Razak, H.A., Subramaniam, V. (2018). Properties of high flowable mortar containing high volume palm oil clinker (POC) fine for eco-friendly construction. Journal of Cleaner Production, vol. 170, 1244-1259, DOI: 10.1016/j.jclepro.2017.09.068.

15. Sandhu, R.K., Siddique, R. (2017). Influence of rice husk ash (RHA) on the properties of self-compacting concrete: A review. Construction and Building Materials, vol. 153, 751-764, DOI: https://doi.org/10.1016/j. conbuildmat.2017.07.165.

16. Prameetthaa, J., Bharatkumar, B.H., lyer, N.R. (2015). Investigation on micronized biomass silica as a sustainable material. Cement \& Concrete Composites, vol. 60, 25-33, DOI: 10.1016/j.cemconcomp.2015.04.004.

17. Kang, S.-H., Hong, S.-G., Moon, J. (2019). The use of rice husk ash as reactive filler in ultra-high performance concrete. Cement and Concrete Research, vol. 115, 389-400, DOI: 10.1016/j.cemconres.2018.09.004. 
18. Gill, A.S., Siddique, R. (2018). Durability properties of self-compacting concrete incorporating metakaolin and rice husk ash. Construction and Building Materials, vol. 176, 323-332, DOI: 10.1016/j.conbuildmat.2018.05.054.

19. Koushkbaghi, M., Kazemi, M.J., Mosavi, H., Mohseni, E. (2019). Acid resistance and durability properties of steel fiber-reinforced concrete incorporating rice husk ash and recycled aggregate. Construction and Building Materials, vol. 202, 266-275, DOI: 10.1016/j.conbuildmat.2018.12.224.

20. Monteny, J., Vincke, E., Beeldens, A., De Belie, N., Taerwe, L., Van Gemert, D., Verstraete, W. (2000). Chemical, microbiological, and in situ test methods for biogenic sulfuric acid corrosion of concrete. Cement and Concrete Research, vol. 30, no. 4, 623634, DOI: 10.1016/S0008-8846(00)00219-2.

21. Yuan, H., Dangla, P., Chatellier, P., Chaussadent, T. (2013). Degradation modelling of concrete submitted to sulfuric acid attack. Cement and Concrete Research, vol. 53, 267-277, DOI: 10.1016/j.cemconres.2013.08.002.

22. Memon, S.A., Arsalan, R., Khan, S., Lo, T.Y. (2012). Utilization of Pakistani bentonite as partial replacement of cement in concrete. Construction and Building Materials, vol. 30, 237-242, DOI: 10.1016/j.conbuildmat.2011.11.021.

23. Laidani, Z.E., Benabed, B., Abousnina, R., Gueddouda, M.K., Kadri, E. (2020). Experimental investigation on effects of calcined bentonite on fresh, strength and durability properties of sustainable self-compacting concrete. Construction and Building Materials, vol. 230, 11, DOI: 10.1016/j.conbuildmat.2019.117062.

24. Mirza, J., Riaz, M., Naseer, A., Rehman, F., Khan, A.N., Ali, Q. (2009). Pakistani bentonite in mortars and concrete as low cost construction material. Applied Clay Science, vol. 45, no. 4, 220-226, DOI: 10.1016/j.clay.2009.06.011.

25. Hu, Y., Diao, L., Lai, Z.Y., He, Y.J., Yan, T., He, X., Wu, J., Lu, Z.Y., Lv, S.Z. (2019). Effects of bentonite on pore structure and permeability of cement mortar. Construction and Building Materials, vol. 224, 276283, DOI: 10.1016/j.conbuildmat.2019.07.073.

26. Man, X.Y., Haque, M.A., Chen, B. (2019). Engineering properties and microstructure analysis of magnesium phosphate cement mortar containing bentonite clay. Construction and Building Materials, vol. 227, DOI: 10.1016/j.conbuildmat.2019.08.037.

27. ASTM C150 / C150M-19a, Standard Specification for Portland Cement, ASTM International, West Conshohocken, PA, 2019.
28. ASTM C618-19, Standard Specification for Coal Fly Ash and Raw or Calcined Natural Pozzolan for Use in Concrete, ASTM International, West Conshohocken, PA, 2019.

29. ASTM C109 / C109M-16a, Standard Test Method for Compressive Strength of Hydraulic Cement Mortars (Using 2-in. or [50-mm] Cube Specimens), ASTM International, West Conshohocken, PA, 2016.

30. ASTM C1437-15, Standard Test Method for Flow of Hydraulic Cement Mortar, ASTM International, West Conshohocken, PA, 2015.

31. ASTM C373-14a, Standard Test Method for Water Absorption, Bulk Density, Apparent Porosity, and Apparent Specific Gravity of Fired Whiteware Products, Ceramic Tiles, and Glass Tiles, ASTM International, West Conshohocken, PA, 2014

32. Alex, J., Dhanalakshmi, J., Ambedkar, B. (2016). Experimental investigation on rice husk ash as cement replacement on concrete production. Construction and Building Materials, vol. 127, 353-362, DOI: 10.1016/j.conbuildmat.2016.09.150.

33. Muthukrishnan, S., Gupta, S., Kua, H.W. (2019). Application of rice husk biochar and thermally treated low silica rice husk ash to improve physical properties of cement mortar. Theoretical and Applied Fracture Mechanics, vol. 104, 12, DOI: 10.1016/j. tafmec.2019.102376.

34. Mesboua, N., Benyounes, K., Benmounah, A. (2018). Study of the impact of bentonite on the physico-mechanical and flow properties of cement grout. Cogent Engineering, vol. 5, no. 1, DOI: 10.1080/23311916.2018.1446252.

35. Rong, Z.D., Ding, J.Y., Cui, Z.J., Sun, W. (2019). Mechanical properties and microstructure of ultra-high performance cement-based composite incorporating RHA. Advances in Cement Research, vol. 31, no. 10, 472-480, DOI: 10.1680/jadcr.17.00209.

36. Gopalakrishnan, R., Jeyalakshmi, R. (2020). The effects on durability and mechanical properties of multiple nano and micro additive OPC mortar exposed to combined chloride and sulfate attack. Materials Science in Semiconductor Processing, vol. 106, DOI: https://doi.org/10.1016/j.mssp.2019.104772

37. Izzat, A.M., Al Bakri, A.M.M., Kamarudin, H., Sandu, A.V., Ruzaidi, G.C.M., Faheem, M.T.M., Moga, L.M. (2013). Sulfuric acid attack on ordinary portland cement and geopolymer material. Revista De Chimie, vol. 64 , no. $9,1011-1014$ 
38. T Nijland, T.G., Larbi, J.A. (2010). Microscopic examination of deteriorated concrete. Maierhofer, C., Reinhardt, H.-W., Dobmann, G. (Eds.), Non-Destructive Evaluation of Reinforced Concrete Structures, Woodhead Publishing, vol. 1, 137-179.

39. Feng, P., Garboczi, E.J., Miao, C.W., Bullard, J.W. (2015). Microstructural origins of cement paste degradation by external sulfate attack. Construction and Building Materials, vol. 96, 391-403, DOI: 10.1016/j. conbuildmat.2015.07.186.
40. Panesar, D.K. (2019). Supplementary cementing materials. Mindess, S. (Eds.), Developments in the Formulation and Reinforcement of Concrete (Second Edition), Woodhead Publishing, 55-85.

41. Boudache, S., Roziere, E., Loukili, A., Colina, H. (2018). Influence of thermal preconditioning on the mechanism of external sulphate attack. Men é ndez, E., Baroghel-Bouny, V.e.r. (Eds.), External Sulphate Attack - Field Aspects and Lab Tests, vol. 21, Springer, Spain 